\title{
18 術中患者監視装置に関する検討
}

生体情報の監視記録装置は医学のみならず多 方面にわたって活用されている. 手術中の患者 管理の面でも多くの分野で使用され，一般にモ ニタと呼ばれている. 今回は，手術中の循環・ 呼吸動態のモニタシステムについて，われわれ の施設での経験に基づいて分析を試みた。

まず，一般に循環・呼吸動態モ二タの歴史的 導入過程をみると，まず生理学方面で使用され た測定技術が，循環器病学 (心臟カテーテル検 查など)，ついで心臟血管外科学を経由して手 術室に持込まれ, 現在では一般手術における術 中患者管理に使用されるようになった.

一方，われわれの施設で使用してきた循環呼 吸動態用モニタについてみると，昭和36年頃， 全手術中央集中監視装置（10室の血圧一非観血 的一心拍数, ECG, 体温等を測定し, 各手術 室の子機と回復室に置かれた中央親機で同時に モニタできる）を試作した。

すべての手術室の生体情報を二重・三重に監 視しょうとする点で特長のある着想であったが， 実際には，生体と機械装着部の不安定性の点と， 電気回路の安定性の点で問題があり，ほとんど

\section{東大 手術部}

都築正和池田和之小林寛伊 歌代一朗 片伊木 毅

使用されないで終った：その間，心臟大血管手 術に際してのモニタと心内圧測定のために，大 型監視記録装置 (Sanborn, Hewlett-Packard) が1台わずかに用いられていた.

昭和48年，まったく構想を新たにした術中モ ニタシステムを導入した，構成は，(1)最重症手 術室用 (8ch，1台), (2)重症手術室用 (4ch，1 台)，(3)一般手術室用（2ch，4台）から成り立 っており，原則として手術室内で使用する．麻 酔医室と講義室には(1)(2)のブラウン管表示と同 じものを表示するように有線配線をしてあり， 麻酔医室でのデータは, 電算機処理用入力とし ても利用されている。これらの術中モニタは昭 和48年 6 月から使用したが，心電図，観血的血 圧計の使用頻度をみると，急激に増加し，昭和 50 年 3 月には，各 150 件，70件に達した。

これらの機器の選定に当たっては, 電気的安 全対策を重視し, 心電計患者電極入力部は浮遊 絶縁型（漏洩電流 $5 \mu \mathrm{A}$ 以下），血圧測定用 Carrier Amp. 回路は，血圧トランスジューサ (H $\mathrm{P}$ 製)，入力部でともに絶縁型となっており，二 重絶縁型と考えてよい。

\section{9 ビデオテープによる手術部学生実習}

\author{
東大 手術部 \\ 小林寛伊池田和之都築正和
}

ビデオテープレコーダ (VTR) は，学校教育 および諸企業において幅広く活用されているが， 医学教育においてはやや遅れをとっている感が ある.VTR には，大規模な放送局用のものと，
小規模な小型 VTR とがあるが，今回われわれ は，手術部学生実習儿小型 VTR を活用するこ とに関して検討を行なったので報告する。

東大中央手術部における学生実習は, 数名単 
位の小グループ制を採用しているが，外科臨床 の基礎知識を指導するにあたり，小型 VTR を 活用する利点は，

1. 即現性

2. 何回も再録画可能

3. 録画中同時再生可能

4. カメラ操作簡単

5. 編集容易

6. ダビング (duplicating) 簡単

7. 維持経費安価

8. 同時録音容易

9. 教材用録画作制が簡単

10. 明所で再生可能

11. 授業中の居眠り防止

12. 繰り返し再生簡単

13. 短時間のデモンストーレションに好適

14. 実習時欠点のクローズアップ可能

15. 手術々式の説明に好適 その他が挙げられ，小型 VTR を活用するにあ たっての欠点としては,

1. 16ミリ映画に比し，解像度が劣る

2. ダビング時解像度低下

3. スローモーション再生時ノイズバー出現

4. 電源の安定性重要

5. 新たなカリキュラムの作制必要

6. 周到な台本またはカメラマンの医学教育 的能力が必要

その他が挙げられる。
利用範囲としては，

1. 手洗い方法

2. 無菌操作

3. 結禁, 縫合方法

4. 手術準備

5. 人工心肺準備, 装着

6. 基本的手術々式

7. Microsurgery

8. 内視鏡

その他がある。

われわれは，手洗い方法，gown technique に関する教材用録画を作制するとともに，手洗 い実習，結禁，縫合法実習に際し，実習状況を 録画，特に，良い点，恶い点をクローズアップ し, 後で再生し, 学生の視覚に訴え, 良好な結 果を得た。このように，外科における基礎知識 の重要性を学生に強く印象づける方法として, 小型 VTR の活用は，非常に有効な手段であり， あわせて，VTR の移動が容易であり，カメラ 操作に慣れれば， 1 人で実習指導をしながら， 録画も可能である。

しかしながら，小型 VTR は，種々の利点を 有しはするが，ただ無計画に活用できるもので はなく，それなりの準備, 検討が重要であるこ とを忘れてはならない。 